\title{
Two New Triterpenes from Basidiomata of the Medicinal and Edible Mushroom, Laetiporus sulphureus
}

\author{
Khadija Hassan ${ }^{1,2,+}$, Blondelle Matio Kemkuignou $1,2,+$ and Marc Stadler $1,2, * \mathbb{D}$ \\ 1 Department of Microbial Drugs, Helmholtz Centre for Infection Research and German Centre for Infection \\ Research (DZIF), Partner Site Hannover/Braunschweig, Inhoffenstrasse 7, 38124 Braunschweig, Germany; \\ Khadija.Hassan@helmholtz-hzi.de (K.H.); Blondelle.MatioKemkuignou@helmholtz-hzi.de (B.M.K.) \\ 2 Institute of Microbiology, Technische Universität Braunschweig, Spielmannstraße 7, \\ 38106 Braunschweig, Germany \\ * Correspondence: Marc.Stadler@helmholtz-hzi.de; Tel.: +49-531-6181-4240 \\ + These authors contributed equally to this work.
}

Citation: Hassan, K.; Matio

Kemkuignou, B.; Stadler, M. Two

New Triterpenes from Basidiomata of the Medicinal and Edible Mushroom, Laetiporus sulphureus. Molecules 2021, 26,7090. https://doi.org/10.3390/ molecules 26237090

Academic Editor: Rubén Tormo

Received: 4 November 2021

Accepted: 23 November 2021

Published: 24 November 2021

Publisher's Note: MDPI stays neutral with regard to jurisdictional claims in published maps and institutional affiliations.

Copyright: (c) 2021 by the authors. Licensee MDPI, Basel, Switzerland. This article is an open access article distributed under the terms and conditions of the Creative Commons Attribution (CC BY) license (https:// creativecommons.org/licenses/by/ $4.0 /)$.
Abstract: In the search for novel anti-infectives from natural sources, fungi, in particular basidiomycetes, have proven to still harbor so much potential in terms of secondary metabolites diversity. There have been numerous reports on isolating numerous secondary metabolites from genus Laetiporus. This study reports on two new triterpenoids, laetiporins $\mathrm{C}$ and $\mathrm{D}$, and four known triterpenes from the fruiting body of $L$. sulphureus. The structures of the isolated compounds were elucidated based on their 1D and 2D nuclear magnetic resonance (NMR) spectroscopic data in combination with high-resolution electrospray mass spectrometric (HR-ESIMS) data. Laetiporin C exhibited weak antifungal activity against Mucor hiemalis. Furthermore, the compounds showed weak antiproliferative activity against the mouse fibroblast L929 and human cancer cell lines, including KB-3-1, A431, MCF-7, PC-3 and A549.

Keywords: Laetiporus sp.; triterpenoids; antimicrobial; antiproliferative

\section{Introduction}

Fungi are a valuable group of organisms that have come under a role of study due to their potential for biological activity [1]. Mushroom-forming fungi (mostly belonging to the phylum Basidiomycota) are known to be prolific producers of bioactive secondary metabolites with economic importance [2,3]. Some of these metabolites have potential benefits with emphasis on their anti-Alzheimer, antidiabetic, anti-malarial, anti-microbial, anti-oxidant, antitumor, anti-viral and hypocholesterolemic activities which are important medicinal targets in terms of drug discovery today [3-5].

The genus Laetiporus belongs to the Fomitopsidaceae (Polyporales) [6] and its species form conspicuous basidiomes on wood. Laetiporus spp. are considered to be forest pathogens, but some taxa are reported to be edible or to contain medicinal valuable compounds [7-9]. The genus is geographically distributed world-wide, and its species can be found in cold temperate to tropical zones. They are most often associated with angiosperm hosts belonging to the Fabaceace, Meliaceae, and Salicaceae families [10]. There are 15 species that have been accepted in the genus worldwide and 11 species have been confirmed in the L. sulphureus complex by phylogenetic analyses [11].

In the present study, Laetiporus sulphureus, a fungus whose fruiting bodies commonly occur in Germany, was investigated. This species is also known under its trivial names such as 'Chicken-of-the-Woods' or 'Chicken Mushroom' [12,13]. It has been used traditionally as food and for its medicinal properties. In recent years, there have been extensive examinations and research into the biologically active compounds and extracts from the species from this genus and their benefits on human health $[12,13]$. We have recently come across fresh specimens from German and found interesting metabolite patterns in 
its fruitbody extracts by HPLC analysis. Hence, we decided to isolate and identified the respective metabolites. This study reports the isolation of two new compounds, for which we propose the trivial names laetiporins $\mathrm{C}$ and $\mathrm{D}$, as well as their structure elucidation and biological activities.

\section{Results and Discussion}

\subsection{Structure Elucidation of Compound 1 and 2}

Investigation of the chemical composition of the fruiting body of Laetiporus sulphureus and subsequent fractionation and purification by reverse phase HPLC (Figure 1) led to the isolation of two previously undescribed lanostane triterpenoids for which the trivial names laetiporins C (1) and D (2) were assigned. In addition, four known compounds: fomefficinic acid (3) [14], eburicoic acid (4) [15], $15 \alpha$-hydroxytrametenolic acid (5) [16] and trametenolic acid (6) [17] were also isolated from the same crude extract (Figure 2). The above-mentioned known compounds except compound 3 were previously isolated from the liquid culture of a Kenyan Laetiporus sp. [12]. The structures of the known compounds were elucidated by comparison of their NMR spectroscopic data and HR-ESIMS with those reported in the literature.

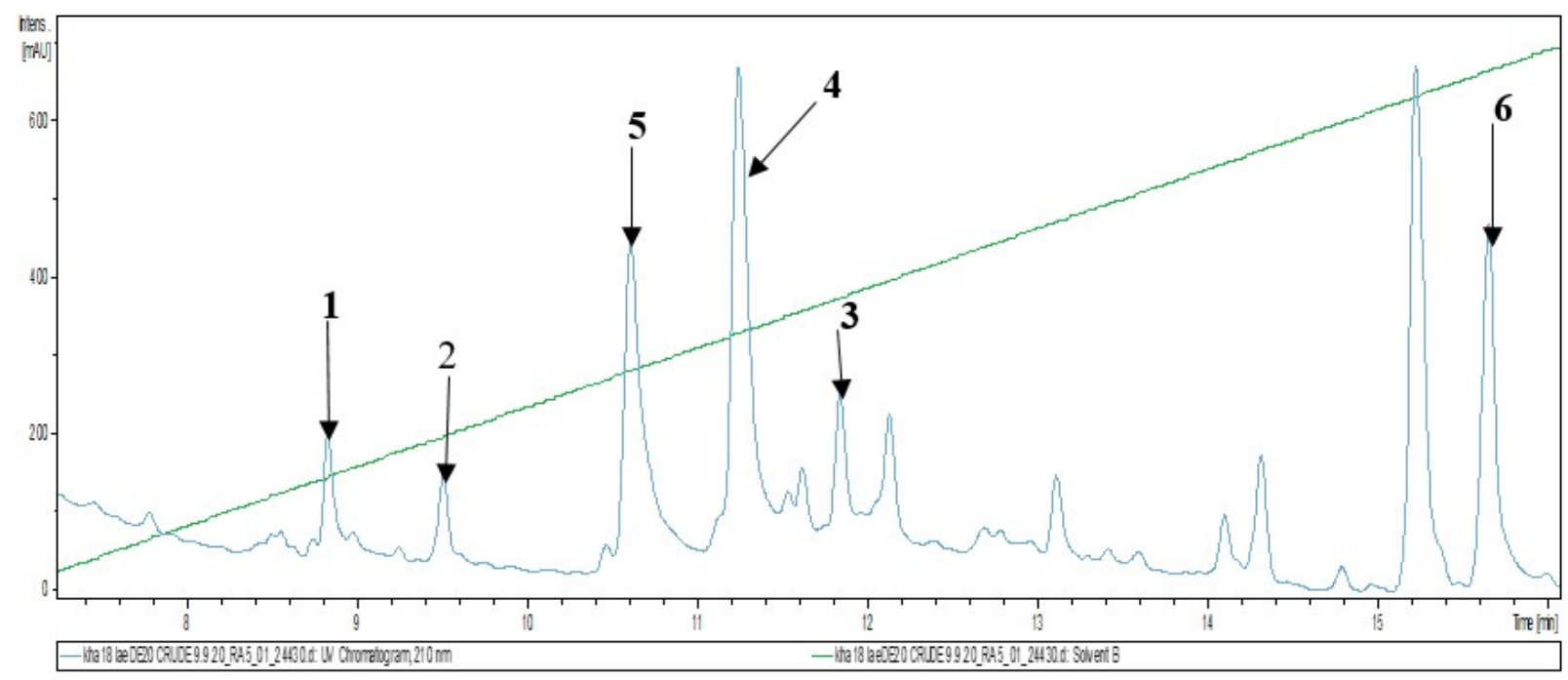

Figure 1. LC-UV/Vis chromatogram of the crude extract from the fruiting body (diode array detection at 200-640 $\mathrm{nm}$ ). Stationary phase: C18 Acquity UPLC BEH column; for gradient and other details on the experimental setup, see the Experimental section; 1-6: Major metabolites detected (chemical structures see Figure 2) The green diagonal line indicates the gradient ( $\%$ of acetonitrile).

Compound $\mathbf{1}$ was isolated as a dark brown solid with the molecular formula $\mathrm{C}_{31} \mathrm{H}_{50} \mathrm{O}_{5}$ and 7 degrees of unsaturation established from HR-ESIMS data (positive mode), which displayed molecular ion peaks $\left[\mathrm{M}+\mathrm{H}-\mathrm{H}_{2} \mathrm{O}\right]^{+}$at $m / z 485.3628$ and $[\mathrm{M}+\mathrm{Na}]^{+}$at $m / z 525.3552$. The ${ }^{1} \mathrm{H}-\mathrm{NMR}$ spectrum exhibited signals of five methyl groups singlet at $\delta 0.70(\mathrm{H}-30, \mathrm{~s})$, $\delta 0.70(\mathrm{H}-18, \mathrm{~s}), \delta 0.81(\mathrm{H}-31, \mathrm{~s}), \delta 0.90(\mathrm{H}-29, \mathrm{~s}), \delta 0.90(\mathrm{H}-19, \mathrm{~s})$, two methyl groups doublet at $\delta 0.94(\mathrm{H}-26 / \mathrm{H}-27, \mathrm{~d}, J=6.8)$, two hydroxymethine at $\delta 3.00(\mathrm{H}-3, \mathrm{td}, J=6.02,10.76)$ and $\delta 4.01(\mathrm{H}-15, \mathrm{br} \mathrm{dd}, J=5.81,10.54)$, two diasteriotopic protons corresponding to one oxymethylene at $\delta 3.98(\mathrm{H}-28 \mathrm{a}, \mathrm{br} \mathrm{d}, J=12.1)$ and $\delta 3.85(\mathrm{H}-28 \mathrm{~b}, \mathrm{br} \mathrm{d}, J=12.2)$, one olefinic protons at $\delta 5.09(\mathrm{H}-23, \mathrm{t}, J=7.31)$ and two hydroxy groups doublet at $\delta 4.30(\mathrm{OH}-3 / \mathrm{OH}-15$, $\mathrm{d}, J=5.3)$. The ${ }^{13} \mathrm{C}$ NMR spectroscopic data revealed the presence of 31 carbons signals further identified based on combined analysis of $1 \mathrm{D}$ and ${ }^{1} \mathrm{H}_{-}{ }^{13} \mathrm{C}$ HSQC spectra as seven methyl groups, eight methylenes, one oxymethylene, four methines, two hydroxymethines, one carboxylic carbon, one olefinic carbon, three non-protonated C-sp ${ }^{2}$ hybridized carbons and four quaternary C-sp $\mathrm{p}^{3}$ hybridized carbons (Table 1). 

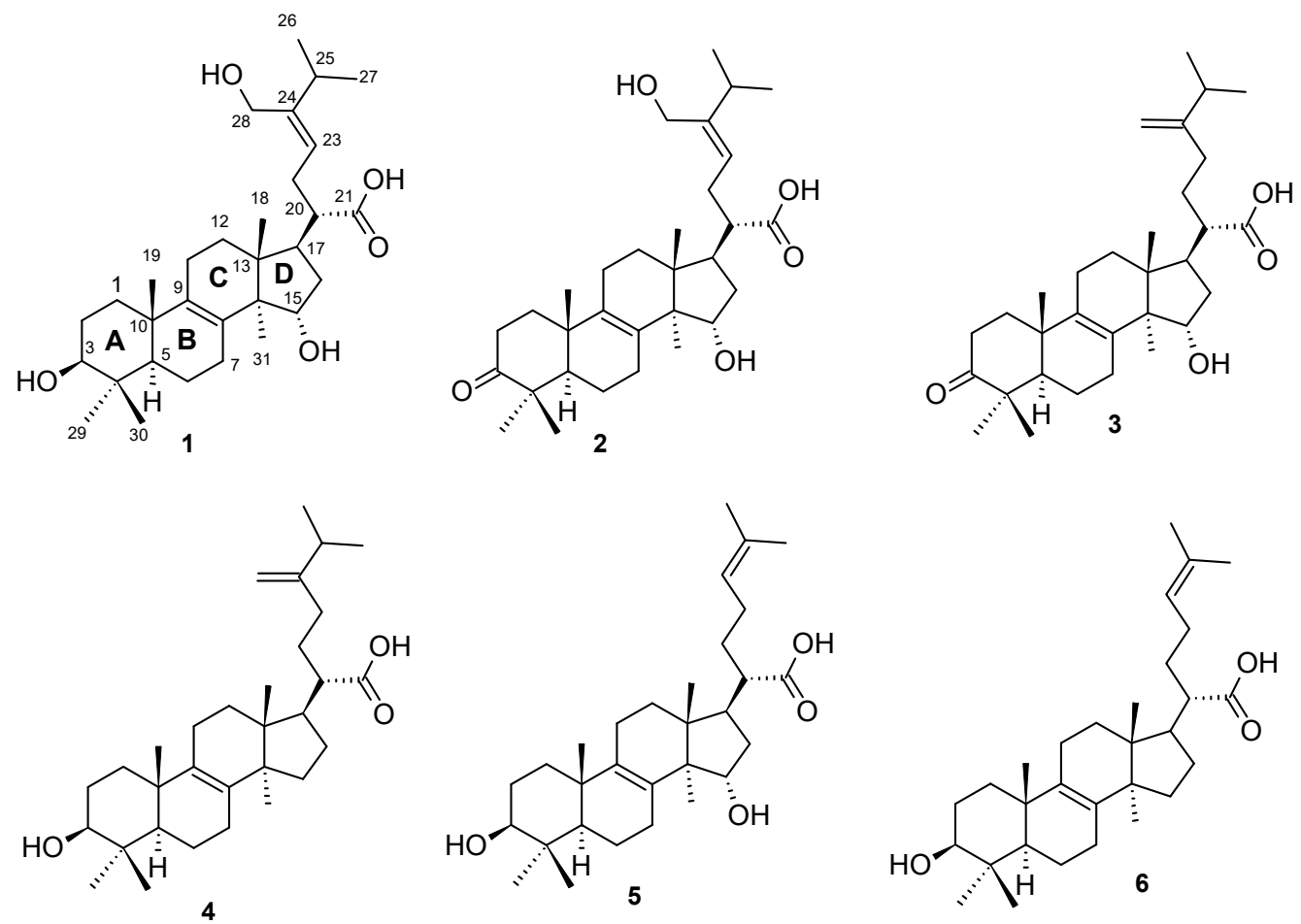

Figure 2. Chemical structures of compounds 1-6 isolated from Laetiporus sulphureus.

Analysis of its HMBC spectrum showed correlations of H-18 $(\delta 0.70)$ to C-12 $(\delta 29.0) / \mathrm{C}$ $13(\delta$ 44.1)/C-14 ( $\delta$ 50.8)/C-17 ( $\delta$ 45.3), H-19 ( $\delta$ 0.90) to C-1 ( $\delta$ 35.2)/C-5 ( $\delta$ 50.0)/C-9 $(\delta$ 133.9)/C-10 $(\delta$ 36.6), H-29 $(\delta$ 0.90) and H-30 ( $\delta$ 0.70) to C-3 $(\delta 76.7) / \mathrm{C}-4(\delta 38.5) / \mathrm{C}-5$ $(\delta 50.0)$ and H-31 ( $\delta 0.81)$ to C-13 ( $\delta 44.1) / C-14(\delta 50.8) / C-15(\delta 71.0)$ which suggested the presence of a lanostane skeleton as previously reported by [12]. The position of the double bond $\Delta^{8-9}$ was confirmed on the HMBC spectrum where correlations between $\mathrm{H}-31(\delta 0.81)$ and C-8 $(\delta 133.9)$ and between $\mathrm{H}-19(\delta 0.90)$ and C-9 $(\delta 134.0)$ was observed. The side chain connection was established from the HMBC correlation of H-20 ( $\delta 2.02)$ to C-17 $(\delta 45.3)$. Further ${ }^{3} \mathrm{~J}-\mathrm{HMBC}$ correlation between the methylene group H-22 ( $\left.\delta 2.15\right)$ and C-21 $(\delta 176.8)$ confirmed the position of the carboxylic group connected at C-20. Moreover, combined analysis of HMBC, COSY and ROESY spectroscopic data of compound 1 confirmed the positioning and assignment of protons and carbons of the side chains (Figure 3). Most particularly, the HMBC correlations observed between $\mathrm{H}-28 \mathrm{a} / \mathrm{H}-28 \mathrm{~b}$ and C-23/C-24/C-25 allowed the positioning of the oxymethylene C-28 placed at C-24. The Z-configuration of the $\Delta^{23-24}$ double bond was established based on ROESY correlations observed between $\mathrm{H}-28 \mathrm{a} / \mathrm{H}-28 \mathrm{~b}$ and $\mathrm{H}-22$ and between $\mathrm{H}-23$ and $\mathrm{H}-25$. In the COSY spectrum, correlations of H-20 to H-17/H-22, H-22 to H-23, H-25 to H-26/H-27 were observed. Further COSY correlations between $\mathrm{H}-1$ and $\mathrm{H}-2, \mathrm{H}-3$ and $\mathrm{H}-2, \mathrm{H}-6$ and $\mathrm{H}-5 / \mathrm{H}-7, \mathrm{H}-11$ and $\mathrm{H}-12, \mathrm{H}-14$ and H-15 were also recorded. A network ROESY correlations, which gave an indication of the orientation in space of some groups at various stereocenters were observed and further allowed the establishment of the absolute configuration of compound 1 . The $\alpha$-orientation of H-3 was suggested based on the ROESY correlations of $\mathrm{H}-3$ to $\mathrm{H}-5 / \mathrm{H}-29$, as well as the coupling constant $J=5.30$ and $10.54 \mathrm{~Hz}$ observed for this proton. Therefore, the $\mathrm{S}$ configuration was assigned at C-3 as previously reported by [12]. By using the orientation of $\mathrm{H}-3$ and the $\mathrm{S}$ configuration assigned to $\mathrm{C}-3$ as reference, the configuration of the other stereocenters was determined based on ROESY correlations observed between $\mathrm{H}-5$ to H-29, H-30 to $\mathrm{H}_{\beta}-6$ (1.61)/H-19, H-19 to $\mathrm{H}_{\beta}-11, \mathrm{H}-18$ to $\mathrm{H}_{\beta}-11$ (1.94)/H-19/H-20/H-15, $\mathrm{H}-31$ to $\mathrm{H}_{\alpha}-16$ (1.82)/H-17. These correlations allowed the assignment of the absolute configuration of compound 1 as $3 S, 5 R, 10 S, 13 R, 14 R, 15 S, 17 R, 20 S$ and the trivial name laetiporin $C$ was attributed to it. 
Table 1. ${ }^{13} \mathrm{C}$ and ${ }^{1} \mathrm{H}-\mathrm{NMR}$ spectroscopic data $\left({ }^{1} \mathrm{H} 700 \mathrm{MH}_{\mathrm{Z}},{ }^{13} \mathrm{C} 175 \mathrm{MH}_{\mathrm{Z}}\right.$ in DMSO-d6, $\delta$ in ppm) for compounds 1 and 2.

\begin{tabular}{|c|c|c|c|c|}
\hline \multirow{2}{*}{ Pos. } & \multicolumn{2}{|r|}{1} & \multicolumn{2}{|c|}{2} \\
\hline & $\delta_{\mathrm{C}}$, Type & $\delta_{\mathrm{H}}(J$ in $\mathrm{Hz})$ & $\delta_{\mathrm{C}}$, Type & $\delta_{\mathrm{H}}(J$ in $\mathrm{Hz})$ \\
\hline 1 & $35.2, \mathrm{CH}_{2}$ & $\begin{array}{l}\alpha: 1.10(\mathrm{~m})^{\mathrm{a}} \\
\beta: 1.62(\mathrm{~m})^{\mathrm{a}}\end{array}$ & $35.4, \mathrm{CH}_{2}$ & $\begin{array}{l}\alpha: 1.52(\mathrm{~m})^{\mathrm{a}} \\
\beta: 1.89(\mathrm{~m})^{\mathrm{a}}\end{array}$ \\
\hline 2 & 27.6, $\mathrm{CH}_{2}$ & $1.48(\mathrm{~m})^{\mathrm{a}}$ & $34.0, \mathrm{CH}_{2}$ & $\begin{array}{l}\alpha: 2.52(\mathrm{~m})^{\mathrm{b}} \\
\beta: 2.33(\mathrm{~m})^{\mathrm{a}}\end{array}$ \\
\hline 3 & $76.7, \mathrm{CH}$ & $3.00($ br dd $), J=5.30,10.54$ & $216.3, \mathrm{C}$ & - \\
\hline 4 & $38.5, \mathrm{C}$ & - & $46.6, \mathrm{C}$ & - \\
\hline 5 & $50.0, \mathrm{CH}$ & $0.92(\mathrm{~m})^{\mathrm{a}}$ & $50.5, \mathrm{CH}$ & $1.50, \mathrm{~m}$ \\
\hline 6 & $17.9, \mathrm{CH}_{2}$ & $\begin{array}{l}\alpha: 1.41(\mathrm{~m})^{a} \\
\beta: 1.61(\mathrm{~m})^{\mathrm{a}}\end{array}$ & $19.0, \mathrm{CH}_{2}$ & $\begin{array}{l}\alpha: 1.50(\mathrm{~m})^{a} \\
\beta: 1.58(\mathrm{~m})^{\mathrm{a}}\end{array}$ \\
\hline 7 & $26.5, \mathrm{CH}_{2}$ & $2.11(\mathrm{~m})^{\mathrm{a}}$ & 26.4, $\mathrm{CH}_{2}$ & $2.15(\mathrm{~m})^{\mathrm{a}}$ \\
\hline 8 & $133.9, \mathrm{C}$ & - & $134.7, \mathrm{C}$ & - \\
\hline 9 & $134.0, \mathrm{C}$ & - & $132.7, \mathrm{C}$ & - \\
\hline 10 & $36.6, \mathrm{C}$ & - & $36.5, \mathrm{C}$ & - \\
\hline 11 & $20.1, \mathrm{CH}_{2}$ & $\begin{array}{l}\alpha: 1.87(\mathrm{~m})^{\mathrm{a}} \\
\beta: 1.94(\mathrm{~m})^{\mathrm{a}}\end{array}$ & $20.2, \mathrm{CH}_{2}$ & $1.94(\mathrm{~m})^{\mathrm{a}}$ \\
\hline 12 & $29.0, \mathrm{CH}_{2}$ & $\begin{array}{l}\alpha: 1.29(\mathrm{~m})^{\mathrm{a}} \\
\beta: 1.64(\mathrm{~m})^{\mathrm{a}}\end{array}$ & $29.1, \mathrm{CH}_{2}$ & $\begin{array}{l}\alpha: 1.28(\mathrm{~m})^{\mathrm{a}} \\
\beta: 1.64(\mathrm{~m})^{\mathrm{a}}\end{array}$ \\
\hline 13 & $44.1, \mathrm{C}$ & - & $44.1, \mathrm{C}$ & - \\
\hline 14 & $50.8, \mathrm{C}$ & - & $50.9, \mathrm{C}$ & - \\
\hline 15 & $71.0, \mathrm{CH}$ & $4.01,(\mathrm{dd}), J=10.54,5.81$ & $71.0, \mathrm{CH}$ & $4.04,(\mathrm{br} \mathrm{dd}), J=10.53,5.80$ \\
\hline 16 & $37.7, \mathrm{CH}_{2}$ & $\begin{array}{l}\alpha: 1.82(\mathrm{~m})^{\mathrm{a}} \\
\beta: 1.65(\mathrm{~m})^{\mathrm{a}}\end{array}$ & $37.7, \mathrm{CH}_{2}$ & $\begin{array}{l}\alpha: 1.84(\mathrm{~m})^{\mathrm{a}} \\
\beta: 1.64(\mathrm{~m})^{\mathrm{a}}\end{array}$ \\
\hline 17 & $45.3, \mathrm{CH}$ & $2.01(\mathrm{~m})^{a}$ & $45.3, \mathrm{CH}$ & $2.03(\mathrm{~m})^{\mathrm{a}}$ \\
\hline 18 & $15.8, \mathrm{CH}_{3}$ & $0.70(\mathrm{~s})$ & $16.2, \mathrm{CH}_{3}$ & $0.74(\mathrm{~s})$ \\
\hline 19 & $18.9, \mathrm{CH}_{3}$ & $0.90(\mathrm{~s})$ & $18.3, \mathrm{CH}_{3}$ & $1.02(\mathrm{~s})$ \\
\hline 20 & $48.1, \mathrm{CH}$ & $2.02(\mathrm{~m})^{\mathrm{a}}$ & $48.0, \mathrm{CH}$ & $2.04(\mathrm{~m})^{\mathrm{a}}$ \\
\hline 21 & $176.8, \mathrm{C}$ & - & $176.8, \mathrm{C}$ & - \\
\hline 22 & $29.9, \mathrm{CH}$ & $2.15(\mathrm{~m})^{\mathrm{a}}$ & $29.9, \mathrm{CH}$ & $2.15(\mathrm{~m})^{\mathrm{a}}$ \\
\hline 23 & $120.6, \mathrm{CH}$ & $5.09(\mathrm{t}), J=7.31$ & $120.6, \mathrm{CH}$ & $5.11(\mathrm{t}), J=7.17$ \\
\hline 24 & $146.3, \mathrm{C}$ & - & $146.4, \mathrm{C}$ & - \\
\hline 25 & $31.4, \mathrm{CH}$ & 2.36 (sep) $J=7.32$ & $31.4, \mathrm{CH}$ & $2.36(\mathrm{~m})$ \\
\hline 26 & $21.9, \mathrm{CH}_{3}$ & $0.94(\mathrm{~d}), J=6.80$ & $21.9, \mathrm{CH}_{3}$ & $0.94(\mathrm{~d}) J=6.71$ \\
\hline 27 & $21.8, \mathrm{CH}_{3}$ & $0.94(\mathrm{~d}), J=6.80$ & $21.8, \mathrm{CH}_{3}$ & $0.94(\mathrm{~d}) \mathrm{J}=6.71$ \\
\hline 28 & $57.5, \mathrm{CH}_{2}$ & $\begin{array}{l}3.98(\text { br d), } J=12.05 \\
3.85(\text { br d), } J=12.21\end{array}$ & $57.5, \mathrm{CH}_{2}$ & $\begin{array}{l}3.99(\mathrm{dd}) J=12.21,5.19 \\
3.86(\mathrm{dd}) J=12.21,5.34\end{array}$ \\
\hline 29 & $28.1, \mathrm{CH}_{3}$ & $0.90(\mathrm{~s})$ & $26.1, \mathrm{CH}_{3}$ & $1.00(\mathrm{~s})$ \\
\hline 30 & $15.8, \mathrm{CH}_{3}$ & $0.70(\mathrm{~s})$ & $20.9, \mathrm{CH}_{3}$ & $0.96(\mathrm{~s})$ \\
\hline 31 & $17.4, \mathrm{CH}_{3}$ & $0.81(\mathrm{~s})$ & $17.5, \mathrm{CH}_{3}$ & $0.85(\mathrm{~s})$ \\
\hline $3-\mathrm{OH}$ & - & 4.30 (d) $J=5.30$ & - & - \\
\hline $15-\mathrm{OH}$ & - & 4.30 (d) $J=5.30$ & - & $4.34(\mathrm{~d}) J=5.65$ \\
\hline
\end{tabular}

a Signals partially obscured, ${ }^{\mathrm{b}}$ Overlapping with solvent peak.

Compound 2 was obtained as a dark brown solid. The molecular formula of $\mathrm{C}_{31} \mathrm{H}_{48} \mathrm{O}_{5}$ (eight degrees of unsaturation) were deduced from the HR-ESIMS data (positive mode) where molecular ion peaks $\left[\mathrm{M}+\mathrm{H}-\mathrm{H}_{2} \mathrm{O}\right]^{+}$at $m / z$ 483.3466, $[\mathrm{M}+\mathrm{H}]^{+}$at $m / z 501.3572$ and $[\mathrm{M}+\mathrm{Na}]^{+}$at $m / z 523.3394$ were observed. The molecular formula assigned to compound 2 showed a deficiency of two hydrogens compared to compound $\mathbf{1}$ suggesting that an oxidation occurred. Extensive analysis of the 1D and 2D-NMR spectroscopic data of 2 indicated its close similarity with compound $\mathbf{1}$ with the only difference being the presence in its structure of a keto carbonyl group at position C-3 instead of the hydroxyl group as in $\mathbf{1}$. This was confirmed on its ${ }^{1} \mathrm{H}-\mathrm{NMR}$ and ${ }^{13} \mathrm{C}-\mathrm{NMR}$ spectra, where the oxygenated methine signal resonating at $\delta 3.00(\mathrm{H}-3$, br dd, $J=5.3,10.54)$ and $\delta 76.74(\mathrm{C}-3)$ in compound 1 was missing and instead a keto carbonyl group was observed at $\delta 216.3$. HMBC correlations of diasteriotopic protons $\mathrm{H}_{\alpha}-1(\delta 1.52), \mathrm{H}_{\beta}-1(\delta 1.89), \mathrm{H}_{\alpha}-2(\delta 2.52)$ and $\mathrm{H}_{\beta}-2(\delta 2.33)$ as well as correlations of H-29 $(\delta 1.00), \mathrm{H}-30(\delta 0.96)$ to carbon C-3 ( $\delta 216.3)$ further supported 
the assignment of the structure of compound 2, for which we propose the trivial name laetiporin D.
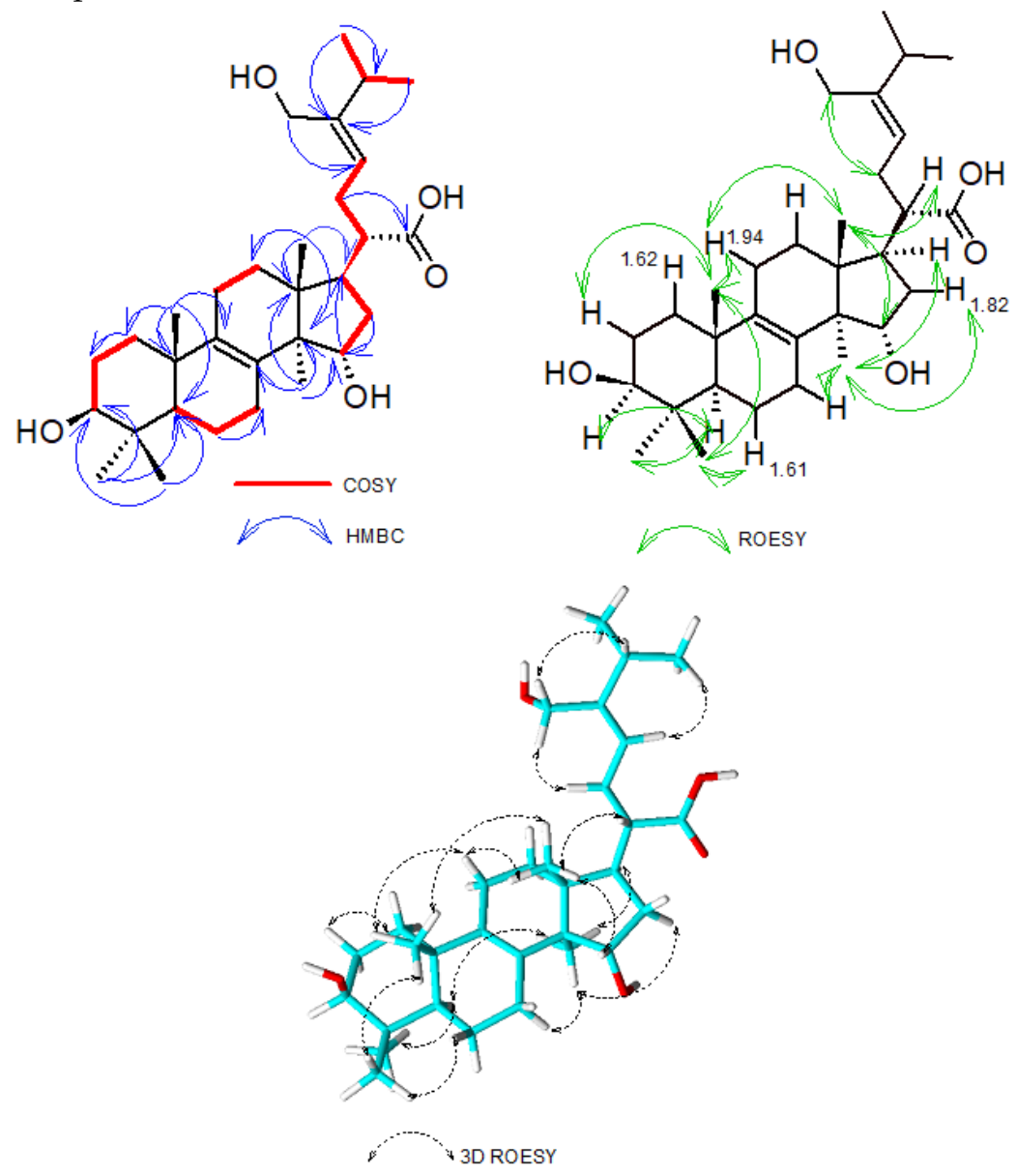

Figure 3. HMBC, COSY, and ROESY correlations of compound 1.

\subsection{Physico-Chemical Characteristics of Compounds $\mathbf{1}$ and $\mathbf{2}$}

Laetiporin C (1): Dark brown solid. [ $\alpha]^{20} \mathrm{D}=+85^{\circ}, \mathrm{UV}$ (DMSO) $\lambda \max (\log \varepsilon) 256$ (3.69) HR-ESIMS $m / z 485.3628\left[\mathrm{M}+\mathrm{H}-\mathrm{H}_{2} \mathrm{O}\right]^{+}, m / z 525.3552[\mathrm{M}+\mathrm{Na}]^{+}$(calcd. for $\mathrm{C}_{31} \mathrm{H}_{50} \mathrm{NaO}_{5}$, 525.3550). For NMR data, see Table 1.

Laetiporin D (2): Dark brown solid. $[\alpha]^{20} \mathrm{D}=+62.8^{\circ}$, UV (DMSO) $\lambda \max (\log \varepsilon) 256$ (3.67) HR-ESIMS $m / z 483.3466\left[\mathrm{M}+\mathrm{H}-\mathrm{H}_{2} \mathrm{O}\right]^{+}, m / z 501.3572[\mathrm{M}+\mathrm{H}]^{+}, m / z 523.3394[\mathrm{M}+\mathrm{Na}]^{+}$ (calcd. for $\mathrm{C}_{31} \mathrm{H}_{48} \mathrm{NaO}_{5}, 523.3394$ ). For NMR data, see Table 1 .

\subsection{Biological Assays}

The new lanostanoids laetiporins C (1) and D (2) were subjected to both, antimicrobial and cytotoxicity assays. For the antimicrobial assay with a wide array of organisms, only laetiporin C showed weak inhibitory effect against Mucor hiemalis (DSM 2656) with MIC $66 \mu \mathrm{g} / \mathrm{mL}$. On the other hand, no inhibition was observed against the other test organisms with both compounds. The isolation of triterpenoids from both edible and inedible mushrooms and their activities has been widely documented in recent years [12,18]. Compounds from mushrooms, for instance, are known to have antimicrobial activity [19].

On the other hand, despite there being numerous reports on the biological activities of the natural lanostane-type triterpenoids like inhibit tumor cell growth, induce apoptosis, and inhibit angiogenesis and metastasis [20,21], these compounds did not have cytotoxic activity in all 6 cell lines. However, there was cell growth inhibition illustrated by five cell lines including L929, A431, A549, PC-3, and MCF-7 with later showing most cell growth inhibited by both compounds. Compound 3 was inactive and the other known 
metabolites 4-6 were not tested, as their activities have previously been reported [12]. A detailed report on their activity is given in the SI (Table S3).

\section{Materials and Methods}

\subsection{General Information}

HPLC-DAD/MS measurements were performed using an amaZon speed ETD (electron transfer dissociation) ion trap mass spectrometer (Bruker Daltonics, Bremen, Germany) and measured in positive and negative ion modes simultaneously. HPLC system (column C18 Acquity UPLC BEH (Waters, Milford, MA USA), solvent A: $\mathrm{H}_{2} \mathrm{O}$; solvent B: acetonitrile (ACN) supplemented with $0.1 \%$ formic acid, gradient conditions: $5 \% \mathrm{~B}$ for $0.5 \mathrm{~min}$, increasing to $100 \% \mathrm{~B}$ in $20 \mathrm{~min}$, maintaining isocratic conditions at $100 \% \mathrm{~B}$ for $10 \mathrm{~min}$, flow rate $0.6 \mathrm{~mL} / \mathrm{min}, \mathrm{UV} /$ Vis detection $200-600 \mathrm{~nm}$ ).

HR-MS (high-resolution mass spectrometry) data were recorded on a MaXis ESITOF (electrospray ionization-time of flight) mass spectrometer (Bruker Daltonics) coupled to an Agilent (Santa Clara, CA, USA) 1260 series HPLC-UV system and equipped with C18 Acquity UPLC BEH (ultraperformance liquid chromatography) (ethylene bridged hybrid) (Waters) column; DAD-UV detection at $200-600 \mathrm{~nm}$; solvent $\mathrm{A}\left(\mathrm{H}_{2} \mathrm{O}\right)$ and solvent $\mathrm{B}(\mathrm{ACN})$ supplemented with $0.1 \%$ formic acid as a modifier; flowrate $0.6 \mathrm{~mL} / \mathrm{min}, 40^{\circ} \mathrm{C}$, gradient elution system with the initial condition $5 \% \mathrm{~B}$ for $0.5 \mathrm{~min}$, increasing to $100 \% \mathrm{~B}$ in $19.5 \mathrm{~min}$ and holding at $100 \% \mathrm{~B}$ for $5 \mathrm{~min}$. To determine the molecular formula, Compass DataAnalysis 4.4 SR1 was used using the Smart Formula algorithm (Bruker Daltonics).

NMR spectra were collected on a Bruker $700 \mathrm{MHz}$ Avance III spectrometer equipped with a $5 \mathrm{~mm}$ TCI cryoprobe $(1 \mathrm{H}: 700 \mathrm{MHz}, 13 \mathrm{C}$ : $175 \mathrm{MHz})$, locked to the respective deuterium signal of the solvent. Optical rotations were measured using Anton Paar MCP150 Polarimeter (Graz, Austria) with $100 \mathrm{~mm}$ path length and sodium D line at $589 \mathrm{~nm}$. The UV spectra were measured on a Shimadzu (Kyoto, Japan) UV/Vis 2450 spectrophotometer using DMSO (Uvasol, Merck, Darmstadt, Germany) as a solvent.

\subsection{Fungal Material}

Laetiporus sulphureus was collected in Braunschweig-Riddagshausen, nature reserve. Plane-table sheet 3729 (1:25,000), $80 \mathrm{~m}$ NHN. Hosts plants were Salix spec, Fagus sylvatica, and Robinia pseudoacacia. The species, which is the only one of the genus known from Central Europe, was identified by Harry Andersson based on morphological data and the identify was confirmed by one of the authors (M.S). A voucher specimen is deposited in the fungarium of the HZI, Braunschweig.

\subsection{Extraction of the Crude Extract}

The fresh specimen (in total $0.8 \mathrm{~kg}$ ) were submerged in $4 \mathrm{~L}$ acetone crushed by a homogenizer and left overnight before extraction [22]. The material was then put in ultrasonic bath for $30 \mathrm{~min}$ before it was filtered, and the solvent evaporated. The remaining aqueous phase $(50 \mathrm{~mL})$ was suspended in an equal amount of distilled water then added to an equal amount $(100 \mathrm{~mL})$ of ethyl acetate, which was later separated by filtration. The supernatant was extracted and filtered through anhydrous sodium sulphate. The resulting ethyl acetate extract was evaporated to dryness by means of rotary evaporator yielding a yellow solid $2.1 \mathrm{~g}$ of crude extract.

\subsection{Isolation of Compounds}

The crude extract was fractionated using preparative reverse phase liquid chromatography (PLC 2020, Gilson, Middleton, WI, USA). VP Nucleodur 100-5C 18 ec column $(250 \times 40 \mathrm{~mm}, 7 \mu \mathrm{m}$ : Macherey-Nagel) used as stationary phase. Deionized water (Milli-Q, Millipore, Schwalbach, Germany) (solvent A) and acetonitrile (solvent B) with $0.05 \%$ TFA was used as eluent with rate of $40 \mathrm{~mL} / \mathrm{min}$. The elution gradient used was $5-100 \%$ solvent $\mathrm{B}$ in $60 \mathrm{~min}$ and thereafter isocratic condition at $100 \%$ solvent B for $5 \mathrm{~min}$. UV detection was carried out at $210-600 \mathrm{~nm}$. Nine fractions were collected according to the observed peaks. 
Out of those, Fractions F3-F5 were combined and further subjected to preparative HPLC with an elution gradient $20-80 \%$ solvent B for $40 \mathrm{~min} 80-100 \%$ for $5 \mathrm{~min}$ and finally isocratic condition at $100 \%$ solvent $B$ for $5 \mathrm{~min}$. Five fractions A1-A5 were collected from this experiment. Fraction A3 was further purified with elution gradient of $40-60 \%$ solvent $\mathrm{B}$ in $35 \mathrm{~min}$ to give compound $2(4.8 \mathrm{mg})$. A similar gradient was applied to fraction A2 to give compound $\mathbf{1}(2.3 \mathrm{mg})$. Fraction A4 was also purified by reverse phase LC (solvent A/solvent B), elution gradient $45-70 \%$ solvent B for $47 \mathrm{~min}$, followed by a gradient shift from $70 \%$ to $100 \%$ in $5 \mathrm{~min}$, and finally isocratic condition at $100 \%$ solvent $\mathrm{B}$ for $5 \mathrm{~min}$ to afford $1.21 \mathrm{mg}$ of compound 3, compound 4 (2.66 mg) and compound 5 $(2.38 \mathrm{mg})$. Compound 6 (4.57 mg), was obtained from F6 with an elution gradient $75-90 \%$ solvent B for $25 \mathrm{~min}$, followed by a gradient shift from $90 \%$ to $100 \%$ in $5 \mathrm{~min}$, and finally isocratic condition at $100 \%$ solvent $\mathrm{B}$ for $5 \mathrm{~min}$.

\subsection{Cytotoxicity Assay}

A panel of six mammalian cell lines including mouse fibroblast L929, HeLa (KB-3-1), epidermoid carcinoma cells A431, breast cancer cells MCF-7, prostate cancer cells PC3 and adenocarcinomic human alveolar basal epithelial cells A549 were chosen in this assay to determine in vitro cytotoxicity $\left(\mathrm{IC}_{50}\right)$ of compounds $\mathbf{1}$ and $\mathbf{2}$. The cell lines were purchased from the DSMZ collection (Braunschweig, Germany). The cell lines L929, A549 and KB-3-1 were cultured in Dulbecco's modified Eagle's medium (DMEM; Gibco; Termo Fisher Scientific, Dreieich, Germany); MCF-7 and A431 cells were cultured in RPMI-1640 medium (Gibco) and PC-3 cells in F12K (Gibco) medium. All media were supplemented with $10 \%$ fetal bovine serum (FBS; Gibco) and incubated under $5 \% \mathrm{CO}_{2}$ at $37{ }^{\circ} \mathrm{C}$ for 5 days. The cytotoxicity assay was performed using the MTT (3-(4,5-dimethylthiazol-2yl)-2, 5 diphenyltetrazolium bromide) test in 96-well microplates in accordance with our standard protocol which have been well previously described [23-25]. Methanol was used as negative control, and epothilone B as the positive control. A detailed protocol and parameters used is given in the Supplementary Materials.

\subsection{Antimicrobial Assay}

The minimum inhibition concentrations (MIC) were determined in serial dilution assay against various test organisms including bacteria: Bacillus subtilis (DSM 10), Staphylococcus aureus (DSM 346), Acinetobacter baumanii (DSM 30008), Chromobacterium violaceum (DSM 30191), Escherichia coli (DSM 1116), Pseudomonas aeruginosa (PA14); Mycobacteria: Mycolicibacterium smegmatis (ATCC 700084); Fungi: Candida albicans (DSM1665), Schizosaccharomyces pombe (DSM 70572), Mucor hiemalis (DSM 2656), Pichia anomala (DSM 6766), and Rhodotorula glutinis (DSM 10134). The assay was excecuted in accordance with literature descriptions [25] and a detailed protocol can be found in the Supplementary Materials.

\section{Conclusions}

Two new triterpenes from L. sulphureus fruiting body, denoted as laetiporins C and D ( $\mathbf{1}$ and $\mathbf{2})$, were isolated in this study. In addition, four known triterpenoids, fomefficinic acid, eburicoic acid, $15 \alpha$-hydroxytrametenolic acid and trametenolic acid (3-6) were also isolated and characterized. The latter compounds except for fomeffinic acid were already isolated previously by Chepkirui et al. [12] from cultures of an African Laetiporus sp. but found devoid of antimicrobial effects and had weak cytotoxicity. Several other triterpenes like laetiposides A-D, laetiporins A-B, sulphurenic acid and dehydroeburicoic acid just to mention these few, have also been isolated previously from Laetiporus spp. This genus could therefore be considered as a prolific source for isolation of lanostanoids-like triterpenes. Although the triterpenes isolated exhibited no cytotoxic effect against the cancer cell lines, the compounds showed antiproliferative activity against the cancer cell lines tested. Laetiporin C (1) only showed weak antifungal activity against the sensitive non-pathogenic zygomycete Mucor hiemalis. Even though the observed activities were relatively weak, the 
isolated compounds are now available for the first time to be tested as pure compounds in a library of fungal metabolites and can be tested for further biological activities.

Supplementary Materials: The following are available online, Figures S1-S37: ESIMS, HR-ESIMS, 1D and 2D NMR spectra of compounds 1-6, Tables S1-S3: Results of biological assays, protocols.

Author Contributions: K.H. contributed to fermentation, isolation of the compounds, determination of biological activities, and manuscript writing; B.M.K. contributed to structure elucidation, analyses of the spectral data, and manuscript writing; M.S. supervised the project, contributed facilities, experimental guidance, edited and polished the manuscript. All authors have read and agreed to the published version of the manuscript.

Funding: Financial support by a personal PhD stipend from the German Academic exchange service DAAD and National Research Fund Kenya NRF to K.H (programme ID-57399475) is greatly acknowledged. B.M.K. is also grateful for financial support by a personal $\mathrm{PhD}$ stipend from the German Academic exchange service DAAD (programme ID-57440921).

Institutional Review Board Statement: Nor applicable.

Informed Consent Statement: Not applicable.

Data Availability Statement: Not applicable.

Acknowledgments: We thank Harry Anderson for collection of specimen. We also thank Wera Collisi and Christel Kakoschke for conducting the cytotoxicity assay and NMR spectroscopic measurements, respectively. The expert assistance in the lab by Silke Reinecke as well as Esther Surges is appreciated. Lastly, we want to thank Josphat Matasyoh for his insightful discussions in chemical structures.

Conflicts of Interest: The authors declare no conflict of interest.

Sample Availability: Samples of the compounds 1-6 are available from the authors.

\section{References}

1. Sandargo, B.; Chepkirui, C.; Cheng, T.; Chaverra-Muñoz, L.; Thongbai, B.; Stadler, M.; Hüttel, S. Biological and chemical diversity go hand in hand: Basidiomycota as source of new pharmaceuticals and agrochemicals. Biotechnol. Adv. 2019, 37, 107344. [CrossRef]

2. Hyde, K.D.; Xu, J.; Rapior, S.; Jeewon, R.; Lumyong, S.; Niego, A.G.T.; Abeywickrama, P.D.; Aluthmuhandiram, J.V.S.; Brahamanage, R.S.; Brooks, S.; et al. The amazing potential of fungi: 50 ways we can exploit fungi industrially. Fungal Divers. 2019, 97, 1-136. [CrossRef]

3. De Silva, D.D.; Rapior, S.; Sudarman, E.; Stadler, M.; Xu, J.; Aisyah Alias, S.; Hyde, K.D. Bioactive metabolites from macrofungi: Ethnopharmacology, biological activities and chemistry. Fungal Divers. 2013, 62, 1-40. [CrossRef]

4. Atanasov, A.G.; Zotchev, S.B.; Dirsch, V.M.; Orhan, I.E.; Banach, M.; Rollinger, J.M.; Barreca, D.; Weckwerth, W.; Bauer, R.; Bayer, E.A.; et al. Natural products in drug discovery: Advances and opportunities. Nat. Rev. Drug Discov. 2021, 20, 200-216. [CrossRef] [PubMed]

5. Beekman, A.M.; Barrow, R.A.; Beekman, A.M.; Barrow, R.A. Fungal metabolites as pharmaceuticals. Aust. J. Chem. 2014, 67, 827-843. [CrossRef]

6. Jiri, P. Will the sulphur polypore (Laetiporus sulphureus) become a new functional food? Glob. J. Med. Clin. Case Reports 2019, 6, 6-9. [CrossRef]

7. Dai, Y.C.; Cui, B.K.; Yuan, H.S.; Li, B.D. Pathogenic wood-decaying fungi in China. For. Pathol. 2007, 37, 105-120. [CrossRef]

8. Saba, E.; Son, Y.; Jeon, B.R.; Kim, S.E.; Lee, I.K.; Yun, B.S.; Rhee, M.H. Acetyl eburicoic acid from Laetiporus sulphureus var. miniatus suppresses inflammation in murine macrophage RAW 264.7 cells. Mycobiology 2015, 43, 131-136. [CrossRef] [PubMed]

9. Martinez, M.; Alvarez, S.T.; Campi, M.G.; Bravo, J.A.; Vila, J.L. Ergosterol from the mushroom Laetiporus sp.; Isolation and structural characterization. Rev. Boliv. Química 2015, 32, 90-94.

10. Song, J.; Cui, B.K. Phylogeny, divergence time and historical biogeography of Laetiporus (Basidiomycota, Polyporales). BMC Evol. Biol. 2017, 17, 102. [CrossRef]

11. Song, J.; Sun, Y.F.; Ji, X.; Dai, Y.C.; Cui, B.K. Phylogeny and taxonomy of Laetiporus (Basidiomycota, Polyporales) with descriptions of two new species from western China. MycoKeys 2018, 37, 57-71. [CrossRef]

12. Chepkirui, C.; Matasyoh, J.C.; Decock, C.; Stadler, M. Two cytotoxic triterpenes from cultures of a Kenyan Laetiporus sp. (Basidiomycota). Phytochem. Lett. 2017, 20, 106-110. [CrossRef]

13. Sułkowska-Ziaja, K.; Muszyńska, B.; Gawalska, A.; Sałaciak, K. Laetiporus sulphureus—Chemical composition and medicinal value. Acta Sci. Pol. Hortorum Cultus 2018, 17, 87-96. [CrossRef] 
14. Wu, X.; Yang, J.; Zhou, L.; Dong, Y. New lanostane-type triterpenes from Fomes officinalis. Chem. Pharm. Bull. 2004, 52, $1375-1377$. [CrossRef] [PubMed]

15. Kariyone, T.; Kurono, G. Constituents of Fomes officinalis Fr. J. Pharm. Soc. Jpn. 1940, 60, 318. [CrossRef]

16. Yang, S.W.; Shen, Y.C.; Chen, C.H. Steroids and triterpenoids of Antodia cinnamomea-a fungus parasitic on Cinnamomum micranthum. Phytochemistry 1996, 41, 1389-1392. [CrossRef]

17. Yoshikawa, K.; Ikuta, M.; Arihara, S.; Matsumura, E.; Katayama, S. Two new steroidal derivatives from the fruit body of Chlorophyllum molybdites. Chem. Pharm. Bull. 2001, 49, 1030-1032. [CrossRef]

18. Wu, Y.L.; Han, F.; Luan, S.S.; Ai, R.; Zhang, P.; Li, H.; Chen, L.X. Triterpenoids from Ganoderma lucidum and their potential anti-inflammatory effects. J. Agric. Food Chem. 2019, 67, 5147-5158. [CrossRef]

19. Dasgupta, A.; Acharya, K. Mushrooms: An emerging resource for therapeutic terpenoids. 3 Biotech 2019, 9, 1-14. [CrossRef]

20. Yaoita, Y.; Kikuchi, M.; Machida, K. Terpenoids and sterols from mushrooms. Stud Nat Prod Chem. 2015, 44, 1-32.

21. Zou, L.W.; Dou, T.Y.; Wang, P.; Lei, W.; Weng, Z.M.; Hou, J.; Wang, D.D.; Fan, Y.M.; Zhang, W.D.; Ge, G.B.; et al. Structure-activity relationships of pentacyclic triterpenoids as potent and selective inhibitors against human carboxylesterase. Front. Pharmacol. 2017, 8, 435. [CrossRef] [PubMed]

22. Cheng, T.; Chepkirui, C.; Decock, C.; Matasyoh, J.C.; Stadler, M. Skeletocutins M-Q: Biologically active compounds from the fruiting bodies of the basidiomycete Skeletocutis sp. collected in Africa. Beilstein J. Org. Chem. 2019, 15, 2782-2789. [CrossRef] [PubMed]

23. Becker, K.; Pfütze, S.; Kuhnert, E.; Cox, R.J.; Stadler, M.; Surup, F. Hybridorubrins A-D: Azaphilone heterodimers from Stromata of Hypoxylon fragiforme and insights into the biosynthetic machinery for azaphilone diversification. Chemistry Eur. J. 2021, 27, 1438-1450. [CrossRef] [PubMed]

24. Primahana, G.; Narmani, A.; Surup, F.; Teponno, R.B.; Arzanlou, M.; Stadler, M. Five tetramic acid derivatives isolated from the Iranian fungus Colpoma quercinum cctu A372. Biomolecules 2021, 11, 783. [CrossRef]

25. Kemkuignou, B.M.; Treiber, L.; Zeng, H.; Schrey, H.; Schobert, R.; Stadler, M. Macrooxazoles A-D, new 2,5-disubstituted oxazole-4-carboxylic acid derivatives from the plant pathogenic fungus Phoma macrostoma. Molecules 2020, 25, 5497. [CrossRef] 